\title{
Soldiers and secretaries: Gendered boundary work in the Swedish Armed Forces
}

\author{
Alma Persson
}

\section{Linköping University Post Print}

\section{N.B.: When citing this work, cite the original article.}

Original Publication:

Alma Persson , Soldiers and secretaries: Gendered boundary work in the Swedish Armed Forces, 2010, Scandinavian Journal of Management, (26), 2, 166-175.

http://dx.doi.org/10.1016/j.scaman.2009.12.004

Copyright: Elsevier

http://www.elsevier.com/

Postprint available at: Linköping University Electronic Press

http://urn.kb.se/resolve?urn=urn:nbn:se:liu:diva-58357 


\title{
Soldiers and secretaries: \\ Gendered boundary work in the Swedish Armed Forces
}

\author{
Alma Persson \\ Department of Thematic Studies \\ Linköping University
}

Summary

What happens when intersecting relations of gender and occupation are challenged by organizational change? In the present article, I explore this question based on a case study in the Swedish Armed Forces; an organization that is currently in a state of substantial transformation. Instead of defending the nation's borders against armed attack, the purpose is now to participate in peacekeeping operations worldwide. When informants construct the "New Armed Forces", they envision changed patterns of both gender and occupation. I show how gender and occupation intersect in informants' use of metaphors and images, analyse constructions of gendered occupational boundaries and problematize their visions for the future. I also add new dimensions to existing research by gendering the theory of boundary work.

\section{KEYWORDS}

Boundary work; Gender relations; Occupational demarcations; Organizational boundaries; Armed Forces; Military profession; Civilian employees 


\title{
Introduction
}

\begin{abstract}
"Sara", a civilian administrator in an international relations department at the Swedish Armed Forces Headquarters, has submitted a suggestion for a project. So has "Eric", a military officer who works as an administrator at a different unit. TheSupreme Commander was to choose between the two suggestions, and this time he has chosen the one Sara delivered. When Eric finds out that her suggestion has been selected over his, he phones Sara to express his frustration. They argue for quite a while about why the Supreme Commander has not selected Eric's project. Eric eventually runs out of factual arguments, but just before hanging up on Sara he hisses, "You are nothing but a damn secretary who knows a bit of English". ${ }^{1}$
\end{abstract}

Eric's reaction, which Sara describes as a "punch to the stomach", illustrates the gender patterns and attitudes that she considers to be part of everyday work in the Swedish Armed Forces. In this case, however, not only gender is at stake. Eric also draws on his professional status as a military officer by referring to her as "nothing but a damn secretary", even though they are both administrators on the same level. In a single sentence, Eric mobilizes his resources both as a man and as an officer in order to diminish Sara's importance and restore an order in which he is superior to her.

When women enter settings traditionally occupied by and associated with men, established gender patterns tend to rupture. As a result, processes of establishing new patterns (or repairing old ones) emerge (Gherardi \& Poggio, 2007). This article is based on a case study in the Swedish Armed Forces, an organization in which relations are changing in several, intersecting ways. At the heart of the study are the organization's changing purpose, gender relations, and occupational relations. Currently, the organization's primary focus is shifting from the defence of national borders to participation in international peacekeeping operations. Although the very purpose of the Swedish Armed Forces used to be to defend the nation's borders using military means, the organization has not been called upon to do so in modern times. However, during the past 50 years a small part of the Armed Forces has participated in armed conflicts outside of the national context, in international missions. These missions are no longer considered marginal activities; instead they are becoming the organization's primary purpose and source of legitimacy (Ydén, 2008).

The Armed Forces is subject to the Swedish Parliament and government, and, more specifically, to the Ministry of Defence. With nearly 20,000 employees, the organization is one of Sweden's largest public administrative authorities. As such, it is faced with many of the same political demands as other public authorities, most of which are far from the logics of war. A multitude of issues such as equal opportunities for men and women, environmental responsibilities, and personnel policy "seem to be assigned at least the same importance by politicians as the Armed Forces' ability to carry out its primary task" (Ydén, 2008:23ff, my translation). Changes in gender relations and occupational relations both stem from the organization's need to adapt to current political pressures. There are demands for a change in gender relations, for greater gender awareness and an increase in the proportion of women among officers and managers. Occupational boundaries between military officers and civilian employees ${ }^{2}$ are also being redrawn. This means, for

\footnotetext{
${ }^{1}$ This story was told to me by Sara, whom I interviewed for a study on the working conditions of civilian women in the Swedish Armed Forces (Pettersson \& Persson, 2005).

2 The terms "military" and "officer" refer to Armed Forces employees whose current positions require military officers' qualifications. "Civilian" refers to Armed Forces employees who hold jobs that do not require military qualifications.
} 
example, that many managerial and other positions that were once reserved for military officers are to be opened up to civilian employees (Regeringen, 2001).

Thus, multiple dimensions of the Swedish Armed Forces are changing, and the process is not a simple one. The changes involve competing interests and different groups in the organization acting to protect their own hard-won turf. In addition, the different dimensions intersect and their connections are not always easy to disentangle. For example, an increased focus on armed combat in foreign missions may not combine easily with an increase in the number of female officers in top positions. There is also the question of what role civilian men and women will play in international missions. In order to capture these and other complexities I use the concept of boundary work, which will be discussed in the following section. As an analytical tool, it helps shed some light on the sometimes subtle tensions between these dimensions and the process of (re)constructing organizational relations. The analysis encompasses forms of boundary work that preserve the status quo as well as forms that challenge established patterns.

Military organizations have long been male-dominated territory, in both a numerical and a symbolic sense (Carreiras, 2006; Pettersson, Persson, \& Berggren, 2008). In the words of one of my informants, the Swedish Armed Forces "is a traditionally male organization and it carries the weight of its history on its shoulders". Until 1980, the military profession in Sweden was reserved exclusively for men. In 1969, when there was a personnel shortage, the Commander of the Air Force requested permission to employ women in non combat military positions in order to free male officers for combat (Kryhl, 1996). Once positions started to open for women in 1980, it did not take long until the formal gendered restrictions were abolished entirely. Women were allowed into all parts of the military in 1989, including combat positions (Berggren, 2002). However, they remained a sensational and highly contested phenomenon for years to come.

Long before they worked in military positions, starting in the early 19th century, women were working in the Armed Forces as civilian employees (Sundevall, 2006). The majority of women in the Armed Forces today are still working in civilian jobs, including administrative, engineering, and management positions. Of the Armed Forces civilian workforce today, 40 percent are women (Försvarsmakten, 2008).

The aim of the present study is to show how gendered occupational boundaries are drawn and redrawn in the Swedish Armed Forces through the practising of boundary work. In the analysis, I show how boundaries are maintained as well as deconstructed when informants use metaphors and images, construct gendered occupational demarcations, and talk about the very purpose of the organization. The creation of distinctions between women and men as well as between occupational groups, here understood as boundary work, is the main focus of the study. The empirical material consists of in-depth interviews with informants in strategic, executive positions. Political pressure from Parliament and the government to achieve more equitable relations between men and women, as well as between military officers and civilian employees, forms an important backdrop.

\section{Theoretical framework}

My primary tool for understanding processes that either reinforce or challenge established relations between occupational groups is the concept of boundary work. This concept was first used in the sociology of science by Gieryn $(1983,1999)$, who employed it to analyse the cultural cartography of science and the quest for epistemic authority. Scientists practise boundary work to create demarcations between "proper science" and "non-science" in order to secure their own power, 
resources, and control. Allen $(2000,2001)$ has developed Gieryn's theoretical framework further in a study of how nurse managers accomplish formal boundaries and negotiate the concrete division of labour in a district general hospital. My understanding of boundary work is strongly influenced by Allen's suggestion that it should be viewed as "micropolitical strategies through which work identities and occupational margins are negotiated" (Allen, 2000:348). However, I argue that one must also take gender into account in order to understand how formal and symbolic authority is negotiated, something that neither Allen nor Gieryn do. As stated by Witz (1992), "professional projects" need to be analysed as gendered projects; the actors involved, as well as the strategies of exclusion and inclusion that they practise, are gendered. Drawing on feminist organization studies, my theoretical contribution lies in the development of a gendered theory of boundary work. Paraphrasing the often-cited words of Acker (1990:146), such an approach can help us understand how advantage and disadvantage, exploitation and control, action and emotion, meaning and identity are patterned through a distinction between men and women (or "masculinity" and "femininity") and between occupational groups. In addition, it can shed light on the intersections between these dimensions of organizational relations.

Concepts related to boundaries have been used in gender studies before. In a classic study of everyday life at an elementary school, Thorne (1993) uses the concept of borderwork to conceptualise interaction across gender boundaries. She stresses that the metaphor of borders should not be interpreted as a static dualism. "The imagery of 'border' may wrongfully suggest an unyielding fence that divides social relations into two parts. The image should rather be one of many short fences that are quickly built and as quickly dismantled. Gender boundaries are episodic and ambiguous" (Thorne, 1993:84). In order to capture the building as well as the dismantling of these episodic fences, I distinguish between two types of boundary work: boundary maintenance and boundary deconstruction. When informants uphold current divisions and reinforce established patterns of gender and occupation, the concept of boundary maintenance is employed. When they argue, for example, that boundaries are unjust or old-fashioned and ought to be abolished, I analyse their accounts as expressions of boundary deconstruction.

Research on practices that enforce or challenge established hierarchies and relations in organizations has been conducted within various fields and from different theoretical angles. In the context of the Armed Forces, there are studies on the debate about women in the military profession and the processes that eventually resulted in the abolition of the last male occupational monopoly in Sweden (Sundevall, 2006), as well as the gendered conditions in the military after women's entry, marked by macho culture, sexual harassment, and unequal working conditions (Berggren, 2002). Carreiras (2006) states that when it comes to gendered and gendering organizations, military organizations are "extreme cases" in three important ways. First, their organizational structure is based on gender divisions that often exclude women from certain positions. Second, the domination of men in numerical terms is a key characteristic. Third, military culture contributes to a reproduction of hegemonic masculine culture and ideology.

The question of relations between occupational groups and between men and women in a military context is not an exclusively Swedish phenomenon. Military organizations in other countries struggle with civil-military relations and issues of gender equality as well (Lomsky-Federer, Gazit, \& Ben-Ari, 2008; Sasson-Levy \& Amram-Katz, 2007; Williams, 1991; Woodward \& Winter, 2004). However, these studies tend to be either-or: focusing either on gender relations or on struggles between occupational groups. Connections between the two are rarely theorized upon. Therefore, one may want to look outside the context of military organizations to research that conceptualises 
the connection between gender relations and occupational relations. Abrahamsen and Gjerberg (2002) sum up one of the main points, stating that the division of labour between occupational groups is not a static phenomenon. On the contrary, it is subject to more or less overt negotiations in which gender plays an important role. Dahle and Iversen (2001) analyse a conflict between two female-dominated occupational groups - nurses and nursing assistants - that boils down to the demarcation between theoretical knowledge and practical know-how. Organizational gender relations can also be understood in terms of group identities, focusing for example on how the gender ascribed to different groups affects everyday work as well as the relationships and boundaries between occupational groups (Sahlin-Andersson, 1994).

I contribute to this field of research by theorizing upon gendered boundary work, that is, the building and dismantling of organizational demarcations, in one of the most apparently gendered and gendering organizations in modern working life: the Armed Forces.

\section{Method and empirical material}

The analysis is based on interviews with nine informants who work in strategic and managerial positions in, or closely related to, the Swedish Armed Forces Headquarters. Each informant was carefully selected, based on his or her knowledge of and influence on the questions that lie at the heart of this study. For ethical reasons, informants cannot be described in detail.Their seniority, degree of specialization, and visibility in the organization make them too easily recognized by anyone even slightly acquainted with the organization. Some informants are past or present members of the highest executive group in the Armed Forces Headquarters. Others are specialists in areas such as human relations, gender equality, and recruitment. Four informants are men and five are women. Four are or have been military officers, andeight are or have been civilian employees. Most likely, the seniority of the interviewees, and their involvement with the issues at hand, affects the ways in which they talk about the organization. Nonetheless, their views are of great importance since they are all, albeit in different ways, active in shaping the future of the organizational relations in the Armed Forces.

The interviews were carried out at each informant's office. They lasted between 90 and 120 min, were digitally recorded, and transcribed in full. The interviews first focused on general changes in the Armed Forces, and then on the informants' views on the present and future gender relations and occupational relations within the Armed Forces. The interviews were loosely structured, leaving space for each interviewee to influence the direction of the discussion, which they did to a great extent. In the interviews, "official" statements mix with personal opinions and informants' reflections on private experiences. Since the informants are easily recognisable, only brief, general descriptions are given when quotations from interviews are presented. Each informant has had an opportunity to read and approve of quotations from his or her interview.

In the analytical process, each interview was thoroughly coded and summarized before the work of identifying potential themes and sub-themes started. Three research questions guide the analysis. First, what symbols and images do the informants draw on and how do these shape the gendered occupational relations in the organization? Second, how are divisions of gender and occupation constructed, and how do these divisions intersect? Third, how do informants envision the organization's gender boundaries and occupational boundaries in the future? The research questions were continuously refined in relation to the empirical material in a back-and-forth movement between ideas, empirical material, previous research, and theoretical concepts. The analysis is 
presented in three parts. In the first part, I focus on the symbolic dimensions of boundary work and analyse how informants use images and metaphors when they talk about the relations between occupational categories or between men and women. Next, the focus shifts from metaphors to informants' constructions of more tangible boundaries of occupation and gender and the working conditions that such demarcations help to shape. Finally, the informants' visions for the future and their understanding of the "New Armed Forces" are discussed.

\section{Metaphors and images as boundary work}

Metaphors and images are important when one wants to understand organizational culture and how distinctions are shaped in organizations. Inspired by a symbolic approach to organizations (Gherardi, 1995), I analyse the ways in which metaphors and images are used to produce systems of meaning that are situated in the specific context of the Swedish Armed Forces. In my interviews, metaphors are used to shed light on important dynamics that are otherwise not discussed very explicitly, for example distinctions between occupational categories and between men and women. Therefore, I consider metaphors and images to be rhetorical devices in the informants' boundary work, and start by analysing their use of insider and outsider metaphors.

\section{"Insiders" and "outsiders": metaphors of the "organizational divide"}

When informants address the problematic relations between occupational groups in the Armed Forces, dualisms, divides, and sides appear across the interviews. When they talk about how they negotiate boundaries between civilians and military officers, informants tend to use a vocabulary of conflict, and even war: the unions organizing employees in the Armed Forces "guard their turf", there are "rivalries" in the organization that sometimes lead to a veritable "battle for positions". When metaphors are used, they imply ways of thinking and seeing that paint a partial yet distinctive picture of the organization (Morgan, 1986). These metaphors highlight conflicting interests and suggest that a war is going on in the organization. In this case, the war is fought over the status that should be given to civilian and military competence as well as the right to certain positions.

There is a vocabulary of dualisms that shapes how occupational relations are discussed in the interviews, and informants often describe the Armed Forces as a divided organization. When they discuss the relations between civilians and military officers, they talk about two "cultures" or "sides" and the differences between them. For example, interviewees who started out as military officers but now work in civilian positions refer to divisions and to life "on both sides". One informant states:

The officer side in [the Armed Forces], it's not the same as on the civilian side. I've been fortunate enough to be both a civilian and an officer here, to see both sides.

When informants use metaphors that draw on "sides" and "divisions", they maintain a boundary between occupational categories. On one side, there are military officers with their own "culture", on the other side there are civilians united by a different "culture". An occupational demarcation separates the two.

Occupational divisions are also expressed in metaphorical terms - of "insiders" and "outsiders" - that have various spatial connotations. For example, civilian employees are described in terms of "coming from the outside". One civilian informant refers to an executive group made up only of military officers as an "inner circle" and a "strategic managerial room" into which he was not allowed. An interviewee argues that he has always felt included despite being an employee "without 
uniform", and says, "I didn't feel like I came from the outside". When the image of outside and inside is added to that of different "sides", the division is no longer a harmless case of complementarity but one where those with power are "inside" and those without are "outside". Interestingly, respondents who seem to support competing agendas use the same images. Informants can do both boundary maintenance and boundary deconstruction by drawing on a set of metaphors that highlight two "sides" and a vocabulary of difference between "insiders" and "outsiders". On the one hand, the metaphors of conflict, divisions, and outsiders and insiders are used to draw attention to unjust organizational demarcations. Some of the informants do boundary deconstruction by using images that highlight unequal conditions in the organization. On the other hand, informants who do boundary maintenance use the same images to explain how the organization works, and should continue to work. In these cases, the terminology is used to describe established organizational relations as complementary and "natural".

Thus, symbols of organizational divisions and hierarchies can be used as rhetorical devices to challenge as well as reaffirm traditional boundaries between the military and civilian employees in the Armed Forces. However, occupational divisions are also coloured by the symbolic construction of gender.

\section{"Core" and "support": gendering the metaphor of insiders and outsiders}

Organizations are sites of symbolic production, and organizational structure is infused with gendered images that either reinforce or challenge gender divisions (Acker, 1990). Few organizations carry a stronger masculine connotation than the military, with its emphasis on physical strength, the traditional image of the soldier and, not least, the gendered symbols of combat and war (Carreiras, 2006). This cultural backdrop influences the everyday activities of the military organization, even those carried out at office desks that look like desks in any other office. It also colours the symbols that the informants use. In this section, I will show how the image of outsiders and insiders intersects with the gendered connotations of another important dualism: core and support.

The masculine symbol of combat is one part of a widespread, dualistic image in the Armed Forces: core and support. Informants describe combat as the "core task" of the organization. That which is not the core tends to be understood as "support", even if it is carried out on a highly strategic level in the organization. Although many military officers work far from the battlefield as teachers, administrators, managers, and meteorologists, they share a joint professional identity that is tied to the image of the soldier in combat. Based on this dualistic understanding, the function of civilians is primarily described as being "supportive" of the military officers. The image of civilians tends to be conflated with women, which leads to the understanding that women's function is to be supportive of men in the organization. Illustrating this phenomenon is a statement by an informant who describes how tasks are divided between the two highest-ranking individuals in the organization: the Supreme Commander and the Director-General:

When the position of Director-General was established [in 2005](...) it was to divide the tasks between the Supreme Commander and the Director-General. That way, the Supreme Commander could concentrate more on the defence- and security policies and the strategic decisions that need to be discussed with the government (...) without having to worry so much about the daily maintenance of the Armed Forces. 
In this quotation, the male officer interviewed draws a line between the Supreme Commander and the Director-General and the tasks they are assigned. The Supreme Commander is described as being responsible for the "strategic decisions" associated with war and high politics. The role of DirectorGeneral is described as one of support and "daily maintenance". This is a division between the highest-ranking military position and the highest-ranking civilian position in the Armed Forces, but is also happens to be a division between the highest-ranking man and the highest-ranking woman. If we take a second look at the quotation above, keeping in mind the gender of the people described, it resembles a stereotypical image of the complementary roles of husband and wife. He deals with the important decisions while she supports his endeavours by taking responsibility for the mundane tasks of "daily maintenance". In this and other interviews, the "core" tends to be ascribed a higher value than the "support". As one informant puts it, "The core is where everyone wants to be". The core/support dualism is also related to a gendered division and hierarchy. This phenomenon is not exclusive to the Armed Forces. Another example is the supportive role that nurses are traditionally assigned in relation to doctors, a role that is very much coloured by the gender identities ascribed to both occupational groups (Sahlin-Andersson, 1994).

Thus, I argue that the image of core and support, where the core is connected to combat and war, provides an important resource for boundary maintenance that strengthens traditional gender divisions. Images that connect, on the one hand, core, combat, and masculinity, and on the other hand, periphery, support, and femininity constitute a powerful rhetorical device for boundary maintenance. Put differently, and drawing on the cultural imagery described above, the Armed Forces could be described as a country. If one were to draw a map of "Armed Forces Land", there would be an area called Combat City that most agree only military officers should inhabit. Even though some still think that Combat City is a men-only territory, women are increasingly asked to migrate there. The city is found at the centre of the map, crucial as it is to the country at large. Closer to the border is Support Village, which is larger than most people think. Nearly half of its approximately 7000 inhabitants are women, and the majority are civilians. Civilians are less costly to employ since they have not been trained for years at the country's expense. Many would say that the main task of the Support Village inhabitants is to be of service to the Combat City residents. Being of service is what civilians, and women, have always done in Armed Forces Land anyway.

In sum, the analysis shows that there are a few crucial images on which informants draw when doing boundary work. The dualism of core and support tends to preserve gendered as well as occupational demarcations. The high value ascribed to core functions and the low value associated with support functions maintain traditional occupational divisions. Adding a gender perspective to the analysis, I show that the gendered link between core and combat contributes further to the perpetuation of traditional organizational boundaries and power relations. How do these symbolic constructions relate to the concrete occupational divisions in the Armed Forces? In the second part of the analysis, more tangible aspects of the "organizational divide" are discussed.

\section{The construction of organizational divisions}

In addition to the use of metaphors and images, I am interested in the respondents' views on the proper place of men and women, and civilians and military officers in the organization. I have shown that informants draw on war metaphors to highlight conflicts between occupational groups in the organization. Now I will show how they discuss how boundaries between occupational groups are negotiated and how gender relations are shaped in everyday work in the Armed Forces. 
Although it is one organization, informants describe the Armed Forces as made up of two separate "systems": one military system and one civilian system. These "separate worlds"each have a certain organizational structure, set of values, working conditions, traditions, and opportunities. But the people who work within the systems are not separated in their day-to-day work. On the contrary, members of the different systems are often colleagues in the same workplace. The differences between occupational conditions for officers and civilians give rise to conflicts and contested boundaries.

Leadership has been one of the areas closely linked to the military system. In recent years, it has become more common for civilians to hold managerial positions, for example in the Armed Forces Headquarters. This change was, and still is, greatly debated. A civilian informant describes what it was like when civilians were first considered for positions as section managers, the most junior of managerial positions in the Headquarters.

\begin{abstract}
Around that time, the first civilian section managers where introduced. The fact that you were supposed to consider competence rather than just the [military] rank, that we could consider civilian section managers in the Headquarters, it was as if we were discussing putting a man on the moon at first.
\end{abstract}

The process of renegotiating career opportunities in the organization and how these should be administrated and divided between the two systems is still on the move. At the heart of the conflict is the question of how competence should be assessed, and what value should be ascribed to military qualifications. In addition, the separate structures of civilians and military officers are debated. Most, but not all, informants call for attempts to form one system rather than two, and would prefer less rigid boundaries between occupational categories. Primarily, they argue that more qualified positions should be made available for civilian employees. A civilian informant states:

\footnotetext{
In my world, in my vision, I think we need to move away from stating that these are military or civilian positions. Instead, we should say that this position requires this competence. This position demands a degree, a military degree, but it also requires this and this and this. That post needs an experienced economist and if that economist has done military service or has some operative military experience, that's a plus. In my world, that's how far we need to go.
}

The informant's vision is that every position in the organization should be analysed in terms of required competence instead of being labelled as a military or civilian job. This can be understood as boundary deconstruction, an inclusionary form of boundary work aimed at challenging rigid occupational divisions that have traditionally been crucial to the organizational structure. Today, all positions are formally labelled as either civilian or military. Instead of these labels, the informant quoted above calls for a more fine-tuned assessment of competence where the demarcation between the two categories is blurred. Another informant describes why she thinks that labelling all positions as either military or civilian is problematic:

Well I think you get stuck in this, military, civilian (...) then there are women and men, it's too big and sprawling in my world. You know what I mean? I want to talk about competence, I want to talk about the right position description to have what it takes to get the job done. I think we have locked ourselves into a corner, with boundaries that are completely unnecessary. 
Later in the interview, this informant argues that the fixed categories of civilian and military positions were established to protect the military profession and preserve traditional organizational relations. She states that military officer representatives have been active in demanding clear-cut occupational boundaries, and that the placement of a civilian in a traditionally military position is "painful" to them. According to her, the division into civilian and military positions is in fact the "root of all evil" and the cause of conflicts between occupational categories. In her opinion, everyone in the organization would benefit from a system with less rigid occupational boundaries.

However, not everyone agrees that the boundaries between occupational categories are too rigid. One informant with a military background states that although the number of qualified civilian positions may increase in the future, the share of civilians will decrease and the division between occupational groups will become even stronger due to the increased focus on international operations:

There are two categories in the Armed Forces for a reason. I mean, the Armed Forces staff is divided into civilians and officers. That's the way it is. (...)Higher demands will be made on many of the civilian employees, not all but many. We might actually have very qualified competences that aren't necessarily officers; I think that will increase to some extent. But at the same time, the number of civilians in the, let's call it the new Armed Forces, it will decrease again. And I think we will find ourselves in more separately defined tasks and roles.

This informant maintains traditional boundaries by neutralizing occupational divisions, stating, "that's the way it is". Highlighting the principle of clearly divided, separate roles for civilians and officers in the organization defends the traditional division of labour.

There is no agreed-upon view on how occupational boundaries are to be drawn, either now or in the future. How the demarcations between the "separate worlds" in the organization are formalized in terms of organizational jurisdiction is not easily deciphered, and the guiding principles aren't always apparent to the informants. For example, the criteria are described as varying from unit to unit, and most informants agree that there is a fair share of arbitrariness involved when the formal lines between civilians and officers are drawn. What might be labelled an exclusively military position at a particular time or in a particular unit may differ in another setting.

The boundaries in the Armed Forces are not carved in stone. On the contrary, they are constantly being defined and redefined, and the boundary work practised by informants is part of that process. Depending on their views on the organizational relations, some informants deconstruct boundaries by questioning their legitimacy and advocating that competence, rather than occupational category, should be the governing principle. Others do boundary maintenance by naturalizing complementary and clearly divided occupational roles, thereby guarding the exclusivity of the military profession against competing occupational groups. There is only one boundary separating civilians and military personnel that informants all seem to agree upon, and that boundary is drawn around armed combat. Being employed in an international operation in a position where combat is required and not having a military officer's training would be a "complete disaster", as one informant puts it. Apart from this distinction, occupational divisions are best described in terms of blurry boundaries and contested terrain. 


\title{
"Double fault" or "one of the boys": gendering the organizational divide
}

Women in the Armed Forces are becoming yesterday's news. Statements like "women don't belong in the military profession" used to be a common feature of public discourse in the organization (Pettersson et al., 2008). Today, this form of resistance seems to have been replaced by subtler forms. In this section, the gendered conditions of day-to-day work in Armed Forces Land are focused, and an organizational divide based not only on occupational categories but also on gender emerges.

When asked whether they regard the Armed Forces to be a gender-equal organization, nearly all of the respondents quickly respond "No". Women respondents, much more than the men I interviewed, indicate that unequal gender relations are somehow holding them back. In addition, occupational boundaries interact with gender boundaries in a way that heightens the women's feelings of being treated as outsiders. There is a common expression in the organization that captures the link between occupation and gender: the "double fault". Civilians often say that they feel like "second class employees" and outsiders in the Armed Forces; women experience double the trouble, being regarded as outsiders in two ways at once. One civilian informant talks about the dynamics between her and her closest colleagues, who are all male military officers:

\begin{abstract}
There are times when I'm not invited to meetings, when they forget me or choose not to invite me. And when I ask, shouldn't I be there, they say, "No, it's only about officers so we didn't think you needed to be there". And I point out that I don't care if it's about officers or civilians, I work on a strategic level and I want the big picture. I wouldn't say I'm thrown out but I'm often forgotten.(...) I react to that, I'm not the same rank and I'm last in line. That's very clear to me, but they don't see it. When I tell [my colleagues], they don't understand, “I don't get it, we haven't done anything, we treat you like everybody else".
\end{abstract}

Although there is no explicit mention of gender in this quotation, the question I had just asked the informant was how she would describe gender equality. What she illustrates above by describing her current workplace is the opposite of equality. She feels "left out" and "forgotten" by her colleagues, and states that this is caused by a combination of her gender and civilian status. When she questions her colleagues' tendencies to exclude her, they do not mention gender when justifying their actions. Rather, "this is a question for officers" is the common response. This informant is convinced, however, that gender plays an important part as well. The obstacles that she describes as being "last in line" and a "third class employee" are related to her status as a woman as well as a civilian. The "double fault" illustrates the ways in which gender and occupation interact to shape unequal working conditions. One interviewee, who currently holds a civilian position, says that at meetings she sometimes casually mentions where she went to military school. When she does, she often finds that the interest in her opinions is greatly increased. When her military background is revealed, one of her two "faults" is eliminated.

A contrasting image of the double fault is described by a male interviewee who states that he has always felt accepted even though he is not "one of the uniforms":

I must say that, personally, I haven't faced resistance because I'm a civilian. (...) When I stepped into this [executive group] I never felt there were any doubts about me, I don't think so. I was accepted as one of the boys, so to speak.

The boundaries of gender and occupation intersect and shape one another in interesting ways. From these two examples, we can almost see the dotted line that connects "officer" and "man" on the 
one hand, and "civilian" and "woman" on the other. It seems that being a woman can heighten the sense of being an outsider as a civilian employee, feeling left out and not being treated as a 'member of the firm". Being a man, however, seems to reduce the gap between occupational categories and create a stronger sense of acceptance and inclusion. Female civilians describe the double fault, while the male civilian quoted above feels like "one of the boys".

Gendered demarcations do not only appear in situations when a male-dominated occupational group competes with a female-dominated one. In the interviews, there are also examples of boundaries between groups of women. One informant refers to this as the "internal divide" between female officers and civilians:

\footnotetext{
People often say that being a woman and a civilian gives you the lowest status. I think that's true. But women officers face problems because of their gender as well. (...)There is this internal divide that I think is apparent between women officers and women civilians. Women officers, often they can't really see that women share a common problem, they're a bit closer [to the norm] and they come even closer by not emphasizing [the problems they share with civilian women]. And that's a problem because otherwise, we could support each other and make this pattern visible and maybe change it a bit.
}

The informant describes how the maintenance of occupational boundaries between groups of women comes from the female officers' fear of creating a gendered demarcation that would separate them from men in the profession. Since female officers want to be perceived as close to the norm of the male officer, the informant argues, they choose to downplay the common interests they may share with women outside of the military profession. For example, attempts to start women's networks in the organization are described as unsuccessful because of the failure to convince potential members that both female officers and female civilians should be included.

When informants talk about boundaries in the Armed Forces, they describe an "organizational divide" that separates civilians from military officers. In addition, there is an "internal divide" that cuts across occupational categories, which separates female officers from female civilians. There is, however, an important difference between occupational demarcations and gender demarcations. Blurry and contested though they may be, there are still formal boundaries between civilians and military officers. Today, there is no such formalized boundary between men and women in the Armed Forces. Assuming that the two dimensions interact, is it possible that formal occupational demarcations are used in order to "do gender" by other words, so to speak? Female civilians state that they are forced to manage resistance in many situations, while the men working "out of uniform" have more positive experiences of being accepted and included even though they are not part of the military profession. The material suggests that resistance against women who disturb traditional gender patterns can draw on more legitimate occupational demarcations. That might help explain why there is such a wide range of expressions to illustrate the experiences of being "last in line", "third class employees" and guilty of the "double fault", and so few accounts of feeling excluded as a man and a civilian employee.

The analysis shows that boundaries between occupational categories are blurry, but that traditional demarcations seem to be in the process of being renegotiated. Among the interviewees, men and women describe the intersection between gender and occupation in very different ways. Being a woman tends to heighten the sense of being an outsider, while being a man can make you "one of the boys" even if you do not wear a uniform. When we move from the everyday experiences of gendered occupational patterns in the organization and talk about the future, however, a different 
picture emerges. In the informants' visions for the future, descriptions of tenacious gender patterns are replaced by accounts of vivid optimism.

\section{Visions of a "New Armed Forces"}

Winds of change are blowing through Armed Forces Land. The "old" Armed Forces that guards the nation's borders is replaced by the logics of a "New Armed Forces". This transformation is described by the Ministry of Defence (2009) as "the biggest reform in modern military history". Informants agree that the transformation into an international operations defence is fundamental, a paradigm shift even, and the organizational relations need to change as a result. In the new organization that they envision, gender relations are more equitable than they have been.

\section{Gender equality goes global}

Major changes have occurred in the last 30 years regarding women's acceptance in the Armed Forces, particularly women in the military profession. Today, it is unlikely that a whole regiment will come to a halt simply because women perform everyday tasks in the exercise area wearing a military uniform, which an informant experienced in the 1980s. When informants discuss the new purpose of the organization, their visions of a "New Armed Forces" are linked to a changed division of labour between men and women. The informants predict that the gender boundaries will continue to be displaced in the future.

In order to understand their optimism, the focus must shift from the national context to a global one. In 2000, the United Nations passed Resolution 1325 on women, peace, and security (United Nations Security Council, 2000). The resolution concerns the victims of war as well as people working in peacekeeping operations. It states that the proportion of female officers in international operations needs to increase, especially in leadership positions, and that a gender perspective is needed in all parts of an operation (Ivarsson, 2004). A military officer informant states that efforts to recruit women for international operations units have increased:

Most of those who recruit staff to an operation comb through the organization to find girls in order to achieve some sort of balance in the unit, simply because it benefits the unit.

According to this informant, the notion that operations benefit from a higher share of women is spreading in the Armed Forces. As a result, female officers are increasingly sought after. Overall, informants share a view on the future Armed Forces as a place where gender boundaries are redrawn. When they link gender equality to combat and international operations, informants construct a future where gender demarcations are substantially displaced. One informant calls the increased focus on international operations "ingenious" because of its effects on the established gender relations:

For us, the consequences are mostly positive; it has made it easier to argue [for gender equality] on a level and in a place where people understand and agree, where there are not just human rights effects but also operational, because it's about the operation. From that point of view this transformation is ingenious; it's as good as it gets.

According to the informant, the overall change when it comes to the gender equality efforts is very positive. It puts the needs of the operation in focus, which highlights the effects of a more even gender distribution in international operations, and moves issues of gender equality from the 
margins towards the centre or "core" of the organization. When gender equality is related to combat, that is, the "core task" of the organization, a crucial and highly gendered boundary is breached. The interest in the presence of women in international missions, however, means that there is an increased focus on a particular group of women: military officers. Thus, Resolution 1325 runs the riskof reinforcing the "internal divide" between groups of women by downplaying questions regarding civilian women and gender equality. When gender boundaries are challenged in the visions for a "New Armed Forces", the demarcation between civilian and military women tends to be reinforced at the same time.

\section{The future of occupational boundaries: contested territory}

The new purpose of the Armed Forces does not only affect the gender relations in the organization, it also stirs things up when it comes to occupational divisions of labour. The transformation of traditional occupational boundaries is linked to the changing purpose of the organization at large. Two differing positions are found among the informants, one doing boundary deconstruction and the other doing boundary maintenance, but both relate their arguments to the organization's new purpose. An informant does boundary deconstruction by describing the "New Armed Forces", stating that the type of competence it will require is different from the past. She calls the transformation towards an international operations defence "a major paradigm shift" that involves both members of the military profession and civilian employees.

The most important change is that we have a completely new purpose. That's the big paradigm shift so to speak, that we are going out internationally. (...) Now we are going where things are dangerous, where you might actually get killed. (...) If we are to remain in this organization, working here as both civilian and officer, you have to be prepared to take on your share of responsibility out there.

The informant describes the "New Armed Forces" as something of an organizational Utopia: it is young, flexible, and modern. In the quotation above, she challenges a fundamental aspect of professional jurisdiction by stating that those sent on international missions in the future will not necessarily have to be military officers, and that civilians need to take on their share of responsibility "out there" as well. Later in the interview, she argues that the number of qualified positions demanding competences other than those acquired during military training will increase in the future. The organization used to be characterized by "bullets and gunpowder" tasks, but new needs lie ahead: for IT personnel, specialists and analysts. In her view, civilians are no longer limited to secretary positions.

Another informant assumes an opposing position regarding how occupational boundaries are to be drawn in the future. When I asked how civilian employees might be affected by the Armed Forces' transformation into an international operations defence, he answered:

Actually, I don't think that the basics are going to change, because the civilian employees mainly remain in the support organization. And the support organization will not be much of a part of the international operations in the future either. Working in a garage or in the administration should be about the same job in the future as it is today.

This informant sustains the traditional logic of the organization by reaffirming the complementary division between "the two categories in the Armed Forces", that is, on the one hand civilian employees and on the other hand military officers. In his view, changes do not imply a new 
occupational division of labour. Civilians are to stay in the "support organization" of the garage or administration while military officers remain the "core competence" of the organization. By stating that civilians are not part of the "core" of the organization, either now or in the future, he reaffirms a traditional boundary based on armed combat.

There are interesting contrasts among informants' views on occupational relations in the future Armed Forces. Starting from a seemingly similar view on what the "New Armed Forces" implies, informants draw very different conclusions. According to some, the new purpose demands that new occupational categories take part in international missions and that occupational boundaries be changed. According to others, the traditional division of labour between occupational groups will remain despite the change of organizational purpose. The major difference between their positions is where they draw the line between occupational groups and what arguments they use to support these boundaries. Again, the image of "core" and "support" is used for doing boundary maintenance by placing military officers "out there" in the battlefield and civilians in the "support organization". On the other hand, arguments that stress the need for qualified civilian competence in international operations challenge the traditional boundary between occupational groups, stating that civilians need to "take on their share of responsibility out there" as well, thus blurring the core/support dualism.

Throughout my interviews, the strongest potential for change is found when informants talk about their visions for the future. Considering the tenacity of both organizational images and social structures discussed in previous sections, one might question the informants' optimism. Their accounts are likely to be coloured by the fact that these changes are partly their responsibility. From that perspective, a more modest interpretation would be that they have high hopes that their work will be fruitful. Informants' boundary deconstruction, aimed at the tenacious dualistic constructs of core/support and the gendered image of combat, has the potential to challenge the status quo of the organization. But it is also possible that while some parts of traditional organizational relations change, related dimensions of this intricate puzzle will remain untouched and continue to preserve these tenacious patterns. For example, there is no way of knowing what will happen if women and/or civilians come to be routinely included in international missions. When one boundary is abolished, others tend to appear in its place. In addition, when occupational relations are renegotiated, gender relations tend to be affected as well, and vice versa.

\section{Conclusions}

In this article, I have focused on how gendered occupational boundaries are challenged and maintained in the Swedish Armed Forces. To come full circle, I will return to where we started, with Eric and Sara and the phone call that ended with Eric hissing "You are nothing but a damn secretary who knows a bit of English". In light of the study presented in this article, this serves as an illustration of the three main points I would like to stress in conclusion.

First, it lends support to the notion that the division of labour between occupational groups is not a static phenomenon. On the contrary, occupational roles, professional status, and working conditions are subject to constant negotiations, and are shaped and reshaped in the everyday work in organizations (Abrahamsen \& Gjerberg, 2002; Allen, 2000). This means that occupational boundaries are not managed or negotiated separately in executive meetings or when policies are written. Rather, they are (re)shaped in the everyday activities in organizations. In addition, the policies and formal regulations that the informants are active in shaping cannot be understood without knowledge of the symbols and images that shape the understanding of organizational 
relations (Gherardi \& Poggio, 2007). For example, gendered dualistic constructs such as combat and support are likely to influence the working conditions, career opportunities, and recruitment outcomes - especially when formal boundaries are blurry. For example, if a certain managerial position is interpreted in a way that links it to leadership in war situations, it is unlikely that a civilian candidate (or a woman) will be considered even if military experience is not a formal requirement.

When Eric hisses at Sara that she is "nothing but a damn secretary", he practises a form of boundary work that maintains an order in which he is superior to her, even though they work on the same hierarchical level. This relates to the second point I want to stress. Boundaries of gender and occupation are not created separately; rather they are intertwined in daily practices and saturated with organizational symbols. Previous studies employing boundary work have not included tools that enable such an analysis (c.f. Allen, 2000). In order to understand what it means to call a colleague a "damn secretary", apart from the apparent rudeness of it, we need to situate the concept in its specific cultural context. In this case, an understanding of gendered organizational symbols is crucial. In the Swedish Armed Forces, "secretary" is a symbol of both a stereotypically feminine category and a civilian one. It draws on the gendered dichotomy of core and support, and is unquestionably placed in the latter category. One might say that Eric has tried to put Sara back in her place, in the gendered "support organization" where she belongs.

Third, Sara's story underlines the positive aspects of this study. The fact that the Supreme Commander chose Sara's project over Eric's supports the informants' general opinion that the gendered occupational structures in the Armed Forces are changing. Eric's insults and attempts to put Sara "back in her place" do not change the outcome of theSupreme Commander's decision. In informants' visions for a "New Armed Forces", new and more equitable relations characterize the organization, for example, because issues of gender are moving towards the "core" of the organization, thus challenging the tenacious link between masculinity and combat. It remains to be seen how deeply rooted symbols and social structures will affect the views on the proper place of women, men, civilians, and military officers in the "New Armed Forces".

The article's theoretical contribution lies in the development of a theory of organizational boundary work that enables the inclusion of multiple dimensions in the analysis. I contribute by gendering the theory of boundary work and showing that a gender perspective is crucial when organizational relations are to be disentangled in this organizational context. Occupational relations in an organization such as the Armed Forces cannot be fully understood if their connection to gender relations is not analysed accordingly, and vice versa. By theorizing upon both boundary deconstruction and boundary maintenance in relation to two intertwined dimensions of the organizational relations, a more multifaceted understanding of how gendered occupational boundaries can be drawn and redrawn is obtained. My overall conclusion is that one dimension of the organizational relations cannot be challenged without affecting the other. Gender relations and occupational relations in the Armed Forces are entangled in a multitude of ways. Boundary maintenance aimed at defending occupational demarcations can draw on stereotypical gender divisions. Similarly, boundary deconstruction aimed at gender divisions can draw on a critique of the illegitimate power of a hegemonic occupational group. Therefore, the process of changing either occupational patterns or gender patterns must take the other dimension into account as well. 


\section{References}

\section{Printed sources}

Abrahamsen, B., \& Gjerberg, E. (2002). Maktrelasjoner i helsetjenestens yrkeshierarki. In A. L. Ellingsæter \& J. Solheim (Eds.), Den usynlige hånd? Kjønnsmakt og moderne arbeidsliv (pp. 291-314). Oslo: Gyldendal akademisk.

Acker, J. (1990). Hierarchies, jobs, bodies: A theory of gendered organizations. Gender and Society, 4(2), 139-158.

Allen, D. (2000). Doing occupational demarcation. The 'boundary work' of nurse managers in a district general hospital. Journal of Contemporary Ethnography, 29(3), 326-356.

Allen, D. (2001). Narrating nursing jurisdiction: 'Atrocity stories' and 'boundary-work'. Symbolic Interaction, 24(1), 75-103.

Berggren, A.W. (2002). Undercover operations in no-women's land: The Swedish Armed Forces through a gender lens. Stockholm: Försvarshögskolan.

Carreiras, H. (2006). Gender and the military. Women in the Armed Forces of Western Democracies. London: Routledge.

Dahle, R., \& Iversen, M. (2001). Relasjonene mellom sykepleiere og hjelpepleiere. Tidskrift for velferdsforskning, 4(4), 239-251.

Gherardi, S. (1995). Gender, symbolism and organizational cultures. London: Sage.

Gherardi, S., \& Poggio, B. (2007). Gendertelling in organizations: Narratives from male-dominated environments. Copenhagen Business School Press.

Gieryn,T.F. (1983). Boundary-work and the demarcation of science from non-science. Strains and interests in professional ideologies of scientists. American Sociological Review, 48(6), 781-795.

Gieryn, T. F. (1999). Cultural boundaries of science: Credibility on the line. Chicago: Univ Press.

Ivarsson, S. (2004). Genusperspektiv på fredsbefrämjande insatser, Försvarsberedningens skriftserie nr 12. Stockholm: Försvarsdepartementet.

Kryhl,T. (1996). Kvinnan tar befälet. Vägen till kvinnliga officerare i svenskt försvar. Militärhistorisk tidskrift, 17, 7-57.

Lomsky-Federer, E., Gazit, N., \& Ben-Ari, E. (2008). Reserve soldiers as transmigrants: Moving between the civilian and military worlds. Armed Forces \& Society, 34(4), 593-614. 
Morgan, G. (1986). Images of organization. Beverly Hills: Sage.

Pettersson, L., \& Persson, A. (2005). Genusrelationer i organisationen Försvarsmakten. Stockholm: Försvarshögskolan.

Pettersson, L., Persson, A., \& Berggren, A. W. (2008). Changing gender relations - women officers' experiences from the Swedish Armed Forces. Economic and Industrial Democracy, 29(2), 192-216.

Regeringen. (2001). Personal i det nya försvaret, Fortsatt förnyelse av totalförsvaret, Regeringens proposition 2001/02:10. Stockholm: Riksdagen.

Sahlin-Andersson, K. (1994). Group identities as building blocks of organizations: A story about nurses' daily work. Scandinavian Journal of Management, 10(2), 131-145.

Sasson-Levy, O., \& Amram-Katz, S. (2007). Gender integration in Israeli Officer Training: Degendering and regendering the military. Paper presented at the annual meeting of the American Sociological Association. New York: TBA.

Sundevall, F. (2006). Det självklara undantaget? Militäryrkena och frågan om kvinnors behörighet till statstjänst (ca 1919-25). Militärhistorisk tidskrift, 27, 87-119.

Thorne, B. (1993). Gender play. Girls and boys in school. Buckingham: Open Univ Press.

United Nations Security Council. (2000). Resolution 1325 on women, peace and security. United Nations.

Williams, C. L. (1991). Gender differences at work: Women and men in non-traditional occupations. Berkeley: Univ of California Press.

Witz, A. (1992). Professions and patriarchy. London: Routledge.

Woodward, R., \& Winter, P. (2004). Discourses of gender in the contemporary British Army. Armed Forces \& Society, 30(2), 279-301.

Ydén, K. (2008). "Kriget" och karriärsystemet. Försvarsmaktens organiserande i fred. Göteborg: Handelshögskolan.

\section{Online sources}

Försvarsmakten. (2008). Armed Forces annual report 2007, appendix 3 personnel report. Retrieved from the website http:// www.mil.se/article.php?id=14812 on April 20th, 2008.

Ministry of Defence. (2009). Areas of responsibility. Retrieved from the website www.sweden.gov.se/sb/d/2060 June 9th, 2009. 